\title{
Supporting Information for \\ Rational ligand design enables pH control over aqueous iron magnetostructural dynamics and relaxometric properties
}

\begin{abstract}
Huan Wang, ${ }^{1}$ Alison Wong, ${ }^{1}$ Luke C. Lewis, ${ }^{3}$ Veronica Clavijo Jordan, ${ }^{1,2}$ Genevieve R. Nemeth, ${ }^{1}$ Jeffrey W. Bacon, ${ }^{4}$ Peter Caravan, ${ }^{1,2}$ Hannah S. Shafaat and, ${ }^{3}$ Eric M. Gale*1,2

${ }^{1}$ The Athinoula A. Martinos Center for Biomedical Imaging and ${ }^{2}$ Institute for Innovation in Imaging, Department of Radiology, Massachusetts General Hospital/ Harvard Medical School, 149 Thirteenth Street, Charlestown, MA 02129 United States. ${ }^{3}$ Department of Chemistry \& Biochemistry, The Ohio State University, 100 West 18th Avenue, Columbus, OH 43210 United States. ${ }^{4}$ Department of Chemistry, Boston University 590 Commonwealth Avenue, Boston, MA 02215 United States. *Correspondence: emgale@mgh.harvard.edu
\end{abstract}

Materials and Methods

Figure S1. LC-MS trace of $\mathrm{H}_{2} \mathrm{PyCy} 2 \mathrm{AI}$.

Figure S2. LC-MS trace of Fe-PyCy2AI.

Figure S3. LC-MS trace of $\mathrm{H}_{2} \mathrm{PyCy} 2 \mathrm{AI}-\mathrm{Me}$

$\mathrm{S} 11$

Figure S4. LC-MS trace of Fe-PyCy2AI.

$\mathrm{S} 12$

Figure S5. HPLC traces demonstrating stability that Fe-PyCy2AI is stable against $\quad$ S12

degredation in solutions of $\mathrm{pH}$ ranging 4.2 to 11.2.

Figure S6. $\mathrm{pH}$ dependence on Fe-PyCy2AI $\mathrm{r}_{1}$ as $\mathrm{pH}$ increases from 4 to 9 , then

S13

back to $\mathrm{pH} 4$.

Figure S7. Concentration dependence on apparent $\mathrm{pK}_{\mathrm{a}}$ of Fe-PyCy2AI water co-

ligand demonstrated by $\mathrm{pH}$ dependence on $\mathrm{r}_{1}$ of $7.0 \mathrm{mM}$ and $0.5 \mathrm{mM}$ samples. Figure S8. Variable temperature 17O T2-relaxometry data for Fe-PyCy2AI at pH $\quad$ S14 6.0 and $\mathrm{pH} 5.0$, and for Fe-DTPA at $\mathrm{pH} 7.4$ Figure S9. CW EPR spectra recorded with $1 \mathrm{mM}$ concentration of Fe-PyCy2AI a $\quad$ S14 at $\mathrm{pH} 4.2$

Figure S10. (A) CW X-band EPR spectra recorded with $1 \mathrm{mM}$ concentration of

Fe-PyCy2AI at $\mathrm{pH} 9.0$

Figure S11. CW X-band EPR spectra showing high field power dependence of Fe-

S15 PyCy2AI at $\mathrm{pH}=7.0$.

Figure S12. Concentration dependence of Fe-PyCy2AI $r_{1}$ at $\mathrm{pH} 9.0,4.7 \mathrm{~T}$ and

S16 $11.7 \mathrm{~T}, 310 \mathrm{~K}$.

Figure S13. Comparison of $\mathrm{pH}$ - and concentration-dependence on Fe-PyCy2AI and Fe-PyCy2AI-Me.

Figure S14. UV-vis data demonstrating rapid reversible interconversion between $\mathbf{M L}(\mathbf{O H})$ and (ML) $)_{2} \mathbf{O}$ between pH 6-7.4.

Figure S15. Kinetics of ML $\mathbf{M L}(\mathbf{O H})$ and $(\mathbf{M L})_{2} \mathrm{O}$ interconversion at $\mathrm{pH} \geq 8.0$ monitored by UV-vis.

Table 1. Crystal data for complex (ML) $)_{2} \mathbf{O}$.

$\mathrm{S} 13$

Table 2. X-ray Data collection parameters for complex (ML) 20.

Table 3. Crystal structure refinement of complex (ML) $\mathbf{O}$. $\quad$ S19

Figure S16. ORTEP diagram of $(\mathbf{M L})_{2} \mathrm{O}$ showing $50 \%$ thermal probability $\quad$ S20

ellipsoids for all non-H atoms with non-H atoms labelled.

Table 4. Geometric parameters for $(\mathbf{M L})_{2} \mathbf{O}$ crystal structure. $\quad$ S20

$\begin{array}{ll}\text { References } & \text { S23 }\end{array}$ 
General. All chemicals and solvents were purchased commercially and used without further purification.

HPLC methods. Liquid chromatography-mass spectrometry (LC-MS) was performed using an Agilent 1260 Series apparatus with an LC/MSD trap and Daly conversion dynode detector with UV detection at 220, 254, and $280 \mathrm{~nm}$ or an Agilent 1260 apparatus interfaced to an Agilent 8800QQQ ICP-MS for Mn detection. The methods used on these systems are as follows: (A1) Waters X-bridge $\mathrm{C} 18$ column $(150 \times 4.6 \mathrm{~mm})$; eluent $\mathrm{A}: \mathrm{H}_{2} \mathrm{O} / 0.1$ \% formic acid, eluent $\mathrm{B}: \mathrm{MeCN} / 0.1$ \% formic acid; gradient: $5 \%$ B for 2 min, $5 \%$ B to $50 \%$ B over 7 min, $50 \%$ B to $95 \%$ B over $1 \mathrm{~min}, 95 \% \mathrm{~B}$ for $2 \mathrm{~min}, 95 \% \mathrm{~B}$ to $5 \% \mathrm{~B}$ for $1 \mathrm{~min}$, then $5 \% \mathrm{~B}$ for $2 \mathrm{~min}$; flow rate $0.7 \mathrm{~mL} / \mathrm{min}$ (used for characterization of ligands and complexes). (A2) Luna C18 column $(100 \mathrm{~mm} \times 2 \mathrm{~mm}$ $100 \AA$ A); eluent C, $10 \mathrm{mM}$ ammonium acetate in water; eluent D, 90\% $\mathrm{MeCN}$ and $10 \% 10 \mathrm{mM}$ ammonium acetate in water; gradient, $5 \% \mathrm{D}$ for $1 \mathrm{~min}, 5 \% \mathrm{D}$ to $95 \% \mathrm{D}$ in $10 \mathrm{~min}, 95 \% \mathrm{D}$ for 2 min, 95 to $5 \% \mathrm{D}$ in $1 \mathrm{~min}, 5 \% \mathrm{D}$ for $1 \mathrm{~min}$; flow rate at $0.7 \mathrm{~mL} / \mathrm{min}$ (used for characterization of synthesis intermediates). The method used for purification are as follows: (P1) Phenomenex C18 column (250 x $21.8 \mathrm{~cm})$; eluent A: H2O/0.1 \% trifluoroacetic acid (TFA), eluent B: MeCN/0.1\% TFA; gradient: starting from $95 \% \mathrm{~A} / 5 \% \mathrm{~B}$ held for $8 \mathrm{~min}$, the fraction of B increased to $50 \%$ over $10 \mathrm{~min}, 50 \%$ to $95 \% \mathrm{~B}$ over 2 min. The column was washed with $95 \%$ B for 3 min and then ramped to $5 \% \mathrm{~B}$ in $2 \mathrm{~min}$. The system was re-equilibrated at $5 \% \mathrm{~B}$ for $3 \mathrm{~min}$; flow rate $15 \mathrm{~mL} / \mathrm{min}$ (used for purification of ligands and complexes). (P2) eluent C: $50 \mathrm{mM}$ ammonium acetate buffer, pH 6.5; eluent D: $10 \% 50 \mathrm{mM}$ ammonium acetate buffer, $\mathrm{pH} 6.5$ and $90 \% \mathrm{MeCN}$; gradient: starting from $95 \% \mathrm{~A} / 5 \% \mathrm{~B}$ held for $8 \mathrm{~min}$, the fraction of B increased to $50 \%$ over $10 \mathrm{~min}, 50 \%$ to $95 \%$ B over 2 min. The column was washed with $95 \%$ B for $3 \mathrm{~min}$ and then ramped to 5\% B in $2 \mathrm{~min}$. The system was re-equilibrated at 5\% B for $3 \mathrm{~min}$; flow rate $15 \mathrm{~mL} / \mathrm{min}$ (used for purification of synthesis intermediates).

Metal ion quantification. Fe complex concentration in solution samples were quantified using an Agilent 8800-QQQ ICP-MS system. Samples with diluted with 0.1\% Triton X-100 in 5\% nitric acid. A linear calibration curve for metal ranging from $1.0 \mathrm{ppb}$ to $1000 \mathrm{ppb}$ Fe was generated daily for the quantification.

NMR. NMR spectra were recorded on a $500 \mathrm{MHz}$ Joel spectrometer. Chemical shifts are reported in $\delta$ (ppm). For ${ }^{1} \mathrm{H}$ and ${ }^{13} \mathrm{C}$ NMR spectra, the residual solvent peaks ${ }^{1}$ were used as internal reference except for ${ }^{13} \mathrm{C}$ NMR recorded in $\mathrm{D}_{2} \mathrm{O}$ where 0.05 wt. \% 3-(trimethylsilyl)propionic-2,2,3,3- $d_{4}$ acid, 
sodium salt was used as the internal reference. Relaxivity measurements were performed on a Bruker mq60 Minispec, $1.41 \mathrm{~T}$, and on a $11.7 \mathrm{~T}$ Varian NMR spectrometer, at $37^{\circ} \mathrm{C}$. Longitudinal $\left(\mathrm{T}_{1}\right)$ relaxation times were measured via an inversion recovery experiment using 10 inversion times of duration ranging between $0.05 \mathrm{~s} T_{1}$ and $5 \mathrm{~s} T_{1}$; transverse $\left(T_{2}\right)$ relaxation times were measured using a Carl-Purcell-Meiboom-Gill spin-echo experiment. Under experimental conditions where $1 / \mathrm{T}_{1,2}$ increased linearly with increasing $[\mathrm{Fe}]$, relaxivity $\left(r_{\mathrm{i}}, \mathrm{i}=1,2\right)$ was determined from the slope of a plot of $1 / T_{i}(i=1,2)$ vs. [Fe] for at least 4 concentrations. Under conditions where nonnegligible dimerization occurs, plots of $1 / \mathrm{T}_{1,2} \mathrm{vs}$. [Fe] are non-linear and $\mathrm{r}_{1,2}$ were estimated by dividing the Fe induced increase in $1 / \mathrm{T} 1,2$ by $[\mathrm{Fe}]$. The transverse $\left(T_{2}\right)$ relaxation times of ${ }^{17} \mathrm{O}$ were acquired at $11.7 \mathrm{~T}$ using a CPMG pulse sequence at temperatures ranging from 298 to $358 \mathrm{~K}$. Samples were prepared in neat $\mathrm{H}_{2} \mathrm{O}$ adjusted and enriched with $\sim 0.5 \% \mathrm{v} / \mathrm{v}$ of $\mathrm{H}_{2}{ }^{17} \mathrm{O}$. The data were fit with the Swift-Connick expressions describing two-site exchange, as described previously. ${ }^{2-5}$

Magnetic Resonance Imaging. Magnetic resonance imaging was performed using a Bruker Biospec 4.7T system. Samples were placed in a homemade sample holder and imaged using a volume coil. The sample holder accommodates simultaneous measurement of up to 60 samples. The sample was incubated at $310 \mathrm{~K}$ by continuously blowing warm air into the scanner bore. Temperature inside the scanner was confirmed using a non-magnetic MR compatible thermometer. $\mathrm{T}_{1}$ values for each compound was determined using a $2 \mathrm{D}$ rapid acquisition refocused echo (RARE) sequence of flip angle $(F A)=90^{\circ}$, echo time $(\mathrm{TE})=20 \mathrm{~ms}$, repetition time $(\mathrm{TR})$ ranging from 146$7500 \mathrm{~ms}$, acquisition matrix $=256 \times 128$, field of view $=64 \times 32 \mathrm{~mm}$, slice thickness $1 \mathrm{~mm} . \mathrm{T}_{1}$ measurements were performed on samples ranging between $0.05-2 \mathrm{mM} \mathrm{Fe}^{3+}$-PyCy2AI. T1 was obtained from a nonlinear least square fit of the signal intensity $(\operatorname{SI}(\mathrm{t}))$ vs TR curve where $\mathrm{T}_{1}$ and $a$ are adjustable parameters, Eq S1,

$$
\mathrm{SI}(\mathrm{t})=\frac{\mathrm{a}\left(1-\mathrm{e}^{-\mathrm{TR} / \mathrm{T} 1}\right)}{1-\mathrm{e}^{-\mathrm{TR} / \mathrm{T} 1} \cos (F A)}=a\left(1-\mathrm{e}^{-\mathrm{TR} / \mathrm{T} 1}\right) \quad(\mathrm{Eq} \mathrm{S} 1)
$$

$\mathrm{T}_{1}$-weighted images were obtained using a 2D RARE spin echo sequence: TR/TE/FA = $250 \mathrm{~ms} / 6.33 \mathrm{~ms} / 90^{\circ}$; acquisition matrix $=256 \times 256$, field of view $=45 \times 45 \mathrm{~mm}$, slice thickness $1 \mathrm{~mm}$.

Potentiometric titrations. $\mathrm{pH}$-potentiometric measurements were performed using an Orion ROSS Ultra $\mathrm{pH}$ electrode and temperature-controlled reaction vessel held at $310 \mathrm{~K}$. A standardized solution of $0.10 \mathrm{M} \mathrm{NaOH}$ was used as the titrant. The electrode was calibrated prior to each titration by titrating a standardized $\mathrm{HCl}_{(\text {aq) }}$ solution at ionic strength 0.10 using $\mathrm{NaCl}$ as the inert 
electrolyte with the standardized $\mathrm{NaOH}$ titrant. A working slope and intercept were generated by plotting $\mathrm{mV}$ as a function of calculated $\mathrm{pH}$, which enabled direct conversion of electrode readings to $\left[\mathrm{H}^{+}\right]$during sample titrations. $\mathrm{pH}$ values recorded during the titrations refers to hydrogen ion concentration. All titration samples were prepared in solutions of $0.10 \mathrm{M} \mathrm{NaCl}$ in distilled, deionized water. Ligand solutions were prepared by dissolving a weighed quantity into the electrolyte and concentration was calculated from the effective weight of the ligand. Moles ligand present in titrand was also confirmed by measuring the mol added $\mathrm{NaOH}$ required to span each inflection point. Solutions of 1:1 ligand: Fe were prepared by adding an appropriate volume of standardized $\mathrm{FeCl}_{3}$ in $0.088 \mathrm{M} \mathrm{HCl}$ solution to a weighed quantity of ligand, the solutions were then adjusted with water and $1 \mathrm{M} \mathrm{NaCl}$ to ionic strength 0.10 . The data was analyzed using the Hyperquad2013 software package. ${ }^{6}$

Estimation of $\log \mathbf{K}$ from EDTA competition assay. The $[\mathrm{Fe}(\mathrm{PyCy} 2 \mathrm{AI})]^{+}$formation constant was estimated from direct competition with EDTA at $\mathrm{pH} 4.4, I=0.1 \mathrm{M} \mathrm{KNO}_{3}, 310 \mathrm{~K}$. Product distribution at equilibrium was estimated from an HPLC analysis of the reaction mixture (HPLC method A1). The equilibrium concentrations of $[\mathrm{Fe}(\mathrm{PyCy} 2 \mathrm{AI})]^{+}$were quantified according to a linear calibration plot of HPLC peak area as a function of chelate concentration. An equilibrium constant, $K_{\text {eq, }}$, was estimated using Eq S2,

$K_{e q}=\frac{[P y C y 2 A I][F e-E D T A]}{[F e-P y C y 2 A I][E D T A]}$

the conditional ( $\mathrm{pH} 4.4$ ) formation constant, $K_{\text {cond }}$, was estimated from $K_{\text {eq }}$ and the previously ( $K_{\text {cond }}$ of Fe-EDTA measured under identical conditions using Eq S3.

$K_{e q}=\frac{K_{\text {cond } F e-E D T A}}{K_{\text {cond } F e-P y C y 2 A I}}$

Under HPLC experimental conditions that cannot distinguish between chemical forms of the complex (ML, MLH, ML(OH) etc), the conditional stability constant can be estimated from the concentration coefficient of the ligand " $\mathrm{L}$ ", or PyCy2 $\mathrm{AI}^{2-}$, species $\left(\alpha_{\mathrm{L}}\right)$, which is known from the ligand $\mathrm{pH}$-titration data. The formation constant was thus estimated using Eq S4.

$K_{\text {cond }}=\alpha_{L} K$

The HPLC assay conditions were chosen specifically to minimize contributions from 'side products' such as $[\mathrm{Fe}(\mathrm{HPyCy} 2 \mathrm{AI})]^{2+},[\mathrm{Fe}(\mathrm{PyC} 2 \mathrm{AI})(\mathrm{OH})]$, or $[\mathrm{Fe}(\mathrm{HEDTA})]$, which together we estimate to contribute $<5 \%$ and $<2 \%$ of total PyCy2AI and EDTA speciation. 
Bulk magnetic susceptibility. The effective mangetic moment moment $\left(\mu_{e f f}\right)$ was estimated using the modified Evans method based on ${ }^{1} \mathrm{H}$ NMR at $310 \mathrm{~K} .{ }^{7-8}$ 7-97-97-97-97-97-9 $\mathrm{Fe}$ complex was dissolved in $\mathrm{H}_{2} \mathrm{O}$ doped with $5 \%$ tert-butanol by volume and placed in a WILMAD coaxial insert tube containing blank solvent doped with $5 \%$ tert-butanol as diamagnetic reference. The molar susceptibilities were determined from the difference in tert-butanol chemical shift between the Fe complex solution and diamagnetic reference according to Eqs S5-6,

$\chi_{M}=\chi_{g} \times M W$

$\chi_{g}=\left|\frac{-3 \Delta f}{4 \pi f m}+\chi_{0}\right|$

where $\chi_{\mathrm{g}}$ and $\chi_{\mathrm{m}}$ are the mass susceptibility and molar susceptibility of the Fe complex, $m$ is the concentration of the Fe complex in $\mathrm{g} / \mathrm{mL}, \Delta f$ is the separation between the resonance frequencies of tert-butanol between the Fe complex solution and diamagnetic reference (in $\mathrm{Hz}$ ), and $f$ is Larmor frequency of water ${ }^{1} \mathrm{H}$ at the field strength of the spectrometer $(499.8 \mathrm{MHz})$, and $\chi_{0}$ is the mass susceptibility of pure solvent $\left(\chi_{0}=-0.7203 \times 10^{-6} \mathrm{~mL} / \mathrm{g}\right.$ for $\left.\mathrm{H}_{2} \mathrm{O}\right)$. The molar susceptibility relates directly to $\mu_{\text {eff }}$ by Eq S7, where $\mathrm{T}$ is temperature.

$\mu_{e f f}=2.84 \sqrt{\chi_{M} T}$

Electron paramagnetic resonance spectroscopy. Solutions of $1 \mathrm{mM} \mathrm{Fe}{ }^{3+}$-PyC2A4Imd were prepared by dissolving the lyophilized powder in $100 \mathrm{mM}$ phosphate buffer ( $\mathrm{pH}$ 4.2-7.8 samples) or $100 \mathrm{mM}$ borate ( $\mathrm{pH} 8.2-9.8$ samples) at the desired $\mathrm{pH}$. The solutions were then transferred into quartz EPR tubes (Wilmad Lab-Glass 727-SQ-250M), and frozen using liquid nitrogen. CW Xband EPR spectra were collected at indicated temperatures and powers at the Analytical Spectroscopy Lab (Ohio State University) using a Bruker EMXPlus instrument equipped with a Cold Edge cryogen-free helium cryostat and recirculation system and an Oxford Instruments MercuryITC temperature controller. All presented spectra were obtained under non-saturating conditions using a microwave frequency of $9.37 \mathrm{MHz}$ and a modulation frequency and amplitude of $100 \mathrm{kHz}$ and $10 \mathrm{G}$, respectively. EPR spectral simulations were performed using the EasySpin (version 5.2.28) toolbox within MATLAB.${ }^{10}$ Background signals were removed from the spectra using a spline subtraction in IGOR Pro 8.04 (Wavemetrics, Lake Oswego, OR) prior to simulation. X-ray Data Collection and Structure Solution Refinement. Single crystals of $\left.\left[\mathrm{Fe}_{(}(\mathrm{PyCy} 2 \mathrm{AI})\right)_{2} \mathrm{O} \bullet 6 \mathrm{H}_{2} \mathrm{O}\right]\left((\mathbf{M L})_{2} \mathrm{O}\right)$ were obtained from $20-25 \mathrm{mM}$ pH 6.7 and $\mathrm{pH} 9.3$ solutions upon standing for 48 hours at room temperature. Dozens of orange square block crystals were 
obtained at $\mathrm{pH} 6.6$, and 2 larger square blocks of orange crystals were obtained at $\mathrm{pH}$ 9.3. A 0.29 $\mathrm{x} 0.22 \times 0.12 \mathrm{mM}$ specimen from the $\mathrm{pH} 6.6$ solution was selected for structural analysis. Unit cell analysis of the crystals isolated from the $\mathrm{pH} 9.3$ sample were confirmed that the structures were identical. Computing details: Data collection: APEX3 (Bruker, 2016); ${ }^{11}$ cell refinement: SAINT V8.40A; ${ }^{12}$ data reduction: SAINT V8.40A; $;^{12} \operatorname{program}(\mathrm{s})$ used to solve structure: ShelXT; ${ }^{13}$ program(s) used to refine structure: SHELXL; ${ }^{13}$ molecular graphics: Olex $2 ;{ }^{14}$ software used to prepare material for publication: Olex $2 .{ }^{14}$

Crystal data, data collection parameters, and structure refinement details, and geometric parameters are shown in Tables S1-S3. The (ML) $)_{2} \mathbf{O}$ crystal structure with atoms labelled is shown in Figure S12.

UV-vis spectroscopy. UV-vis spectra were recorded on a SpectraMax M2 spectrophotometer using quartz cuvettes with a $1 \mathrm{~cm}$ path length. Extinction coefficients recorded at $\mathrm{pH} 9\left(\varepsilon, \mathrm{M}^{-1} \mathrm{~cm}^{-}\right.$ 1) were estimated by dividing absorbance by sample Fe concentration.

Estimation of dissociation constant. The dissociation constant for $(\mathbf{M L})_{2} \mathbf{O}$ formation was estimated from the concentration dependence on $\mathrm{r}_{1}$ at $\mathrm{pH} 9.0$, under these experimental conditions, complexes speciation is comprised near entirely by $\mathbf{M L}(\mathbf{O H})$ and the corresponding $(\mathbf{M L})_{2} \mathbf{O}$ dimer and $\mathrm{r}_{1}$ can be expressed as Eq $\mathrm{S} 8$,

$r_{1}=r_{1}^{\text {mon }} \alpha_{m o n}+r_{1}^{\text {dim }} \alpha_{d i m} \quad$ Eq S8

where $r_{1}{ }^{\text {mon }}$ and $r_{1}{ }^{\text {dim }}$ are the $r_{1}$ corresponding to $\mathbf{M L}(\mathbf{O H})$ and $(\mathbf{M L})_{2} \mathbf{O}$ and $\alpha_{\text {mon }}$ and $\alpha_{\text {dim }}$ are the fraction of total $[\mathrm{Fe}]$ comprised by each.

The concentration dependence on monomer vs. dimer speciation is governed by the equilibrium constant $\left(\mathrm{K}_{\mathrm{d}}\right)$ in Eq $\mathrm{S} 9$.

$K_{d}=\frac{[\text { mon }][\text { mon }]}{[\text { dimer }]}=\frac{([F e]-2[\text { dimer }])([F e]-2[\text { dimer }])}{[\text { dimer }]} \quad$ Eq S9

Eq S9 can be rearranged to the corresponding quadratic equation, Eq S10, and concentration of dimer solved by Eq S11.

$0=4[\mathrm{Fe}]^{2}-[\mathrm{dim}]\left(4[\mathrm{Fe}]+K_{d}\right)+4[\mathrm{dim}]^{2} \quad$ Eq S10

$[d i m]=\frac{\left(4[F e]+K_{d}\right)-\sqrt{\left(4[F e]+K_{d}\right)^{2}-16[F e]^{2}}}{8} \quad$ Eq S11

Thus, the concentration dependence on $r_{1}$ was fit to a 3 parameter fit based on Eqs S8-11, yielding estimates of $\mathrm{r}_{1}{ }^{\mathrm{mon}}, \mathrm{r}_{1}{ }^{\mathrm{dim}}$, and $K_{\mathrm{d}}$. 


\section{Synthesis.}

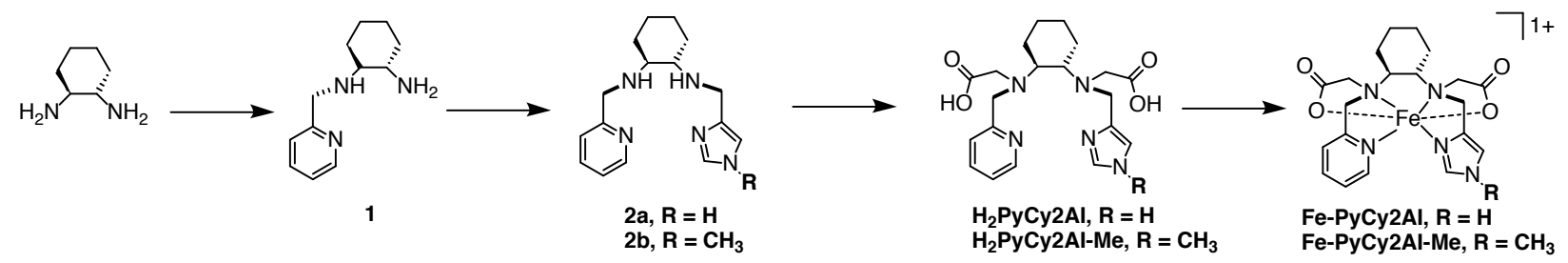

Figure S1. The synthesis of ligands PyCy2AI and PyCy2AI-Me.

( \pm )-trans- $N$-(picolyl)-1,2-Diaminocyclohexane, (1) was synthesized as previously described. ${ }^{15}$ ( \pm )-trans- $N$-((1H-imidazol-4-yl)methyl)- $N$ '-(picolyl)cyclohexane-1,2-diamine, (2a). To a stirring solution of 1 ( $0.50 \mathrm{~g}, 2.44 \mathrm{mmol}, 1$ equiv. $)$ in methanol was slowly added 4imidazolecarboxaldehyde $(0.29 \mathrm{~g}, 3.04 \mathrm{mmol}, 1.25$ equiv. $)$. The mixture was stirred for $2 \mathrm{~h}$ at room temperature, followed by concentrating to dryness. The mixture was dissolved in $50 \mathrm{~mL}$ of dichloromethane, and added to a stirring solution of sodium borohydride $(0.46 \mathrm{~g}, 12.20 \mathrm{mmol}, 5$ equiv.) in $150 \mathrm{~mL}$ methanol over a period of $30 \mathrm{~min}$. The mixture was stirred for $2 \mathrm{~h}$ followed by addition of distilled water. The solvent was removed under reduced pressure, leading to a white solid. The solid was then dissolved in water, adjusted to $\mathrm{pH}>11$ by addition of $1 \mathrm{M} \mathrm{NaOH}$, and washed three times with dichloromethane. The combined organic layer was evaporated under reduced pressure, resulting in a colorless oil. The oil was dissolved in water, adjusted to $\mathrm{pH} 6.5$ with $6 \mathrm{M} \mathrm{HCl}$, and purified by preparative RP-HPLC using the $\mathrm{C} 18$ column and method P2. RPHPLC fractions containing pure product 2a were freeze dried to yield product as a white solid (0.50 g, $1.76 \mathrm{mmol}, 76 \%) .{ }^{1} \mathrm{H}$ NMR (500 MHZ, $\left.\mathrm{CD}_{3} \mathrm{OD}\right): \delta 8.35$ (t, $\left.J=4.3 \mathrm{~Hz}, 1 \mathrm{H}\right), 7.76(\mathrm{~m}, 2 \mathrm{H})$, $7.44-7.37$ (t, $J=6.7 \mathrm{~Hz}, 1 \mathrm{H}), 7.25(\mathrm{~m}, 2 \mathrm{H}), 4.21$ (dd, $J=14.0,5.3 \mathrm{~Hz}, 1 \mathrm{H}), 4.12$ (dd, $J=15.1$, $5.3 \mathrm{~Hz}, 1 \mathrm{H}), 4.04$ (dd, $J=14.0,4.8 \mathrm{~Hz}, 1 \mathrm{H}), 3.94$ (dd, $J=15.4,5.3 \mathrm{~Hz}, 1 \mathrm{H}), 2.73$ (m, 1H), 2.50 $(\mathrm{m}, 1 \mathrm{H}), 2.22(\mathrm{~d}, J=12.8 \mathrm{~Hz}, 2 \mathrm{H}), 1.78(\mathrm{~m}, 2 \mathrm{H}), 1.27(\mathrm{~m}, 2 \mathrm{H}) .{ }^{13} \mathrm{C}$ NMR (125.7 MHZ, CD $\left.{ }_{3} \mathrm{OD}\right)$ : $\delta 177.95$ (acetate), 157.93, 148.34, 137.46, 136.10, 131.87, 122.78, 122.60, 118.15, 60.24, 59.12, 49.47, 41.36, 30.07, 28.18, 24.37, 24.05, 22.28 (acetate). ESI-MS: m/z = $286.2[\mathrm{M}+\mathrm{H}]^{+}$; ESI-MS calculated for $\left[\mathrm{C}_{16} \mathrm{H}_{23} \mathrm{~N}_{5}+\mathrm{H}\right]^{+}: \mathrm{m} / \mathrm{z}=286.2$.

( \pm )-trans- $N$-((1-methyl-1H-imidazol-4-yl)methyl)- $N$ '-(picolyl)cyclohexane-1,2-diamine, (2b). To a stirring solution of 1 ( $0.50 \mathrm{~g}, 2.44 \mathrm{mmol}, 1$ equiv. $)$ in methanol was slowly added 1-methyl$1 \mathrm{H}$-imidazole-4-carbaldehyde (0.34 g, $3.04 \mathrm{mmol}, 1.25$ equiv.). The mixture was stirred for $2 \mathrm{~h}$ at room temperature, followed by concentrating to dryness. The mixture was dissolved in $50 \mathrm{~mL}$ of 
dichloromethane, and added to a stirring solution of sodium borohydride $(0.46 \mathrm{~g}, 12.20 \mathrm{mmol}, 5$ equiv.) in $150 \mathrm{~mL}$ methanol over a period of $30 \mathrm{~min}$. The mixture was stirred for $2 \mathrm{~h}$ followed by addition of distilled water. The solvent was removed under reduced pressure, leading to a white solid. The solid was then dissolved in water, adjusted to $\mathrm{pH}>11$ by addition of $1 \mathrm{M} \mathrm{NaOH}$, and washed three times with dichloromethane. The combined organic layer was evaporated under reduced pressure, resulting in colorless oil. The oil was dissolved in water, adjusted to $\mathrm{pH} 6.5$ with $6 \mathrm{M} \mathrm{HCl}$, and purified by preparative RP-HPLC using the C18 column and method P1. RP-HPLC fractions containing pure product were freeze dried to yield $\mathbf{2} \mathbf{b}$ as a white solid. $(0.60 \mathrm{~g}, 1.45 \mathrm{mmol}$, 60\%). ${ }^{1} \mathrm{H}$ NMR (500 MHZ, CD $\left.{ }_{3} \mathrm{OD}\right): \delta 8.77(\mathrm{~s}, 1 \mathrm{H}), 8.60(\mathrm{~d}, \mathrm{~J}=5.0 \mathrm{~Hz}, 1 \mathrm{H}), 7.96(\mathrm{td}, \mathrm{J}=7.7$, $1.9 \mathrm{~Hz}, 1 \mathrm{H}), 7.55(\mathrm{~d}, \mathrm{~J}=7.7 \mathrm{~Hz}, 1 \mathrm{H}), 7.52(\mathrm{~s}, 1 \mathrm{H}), 7.48(\mathrm{dd}, \mathrm{J}=7.7,4.9 \mathrm{~Hz}, 1 \mathrm{H}), 4.47$ (d, J = 15.2 Hz, 1H), $4.33(\mathrm{~d}, \mathrm{~J}=15.2 \mathrm{~Hz}, 1 \mathrm{H}), 4.17(\mathrm{~d}, \mathrm{~J}=14.6 \mathrm{~Hz}, 1 \mathrm{H}), 3.90$ (d, J = 18.9 Hz, 3H), 2.89 (td, $\mathrm{J}=11.2,4.2 \mathrm{~Hz}, 1 \mathrm{H}), 2.71(\mathrm{td}, \mathrm{J}=10.9,4.0 \mathrm{~Hz}, 1 \mathrm{H}), 2.29(\mathrm{t}, \mathrm{J}=13.5 \mathrm{~Hz}, 2 \mathrm{H}), 1.83(\mathrm{t}, \mathrm{J}=10.3$ $\mathrm{Hz}, 2 \mathrm{H}), 1.42(\mathrm{qd}, \mathrm{J}=12.3,4.0 \mathrm{~Hz}, 1 \mathrm{H}), 1.38-1.28(\mathrm{~m}, 1 \mathrm{H}), 1.27-1.12(\mathrm{~m}, 1 \mathrm{H}) .{ }^{13} \mathrm{C}$ NMR (125.7 MHZ, $\mathrm{CD}_{3} \mathrm{OD}$ ): $\delta 161.71$ (TFA), 161.43 (TFA), 161.15 (TFA), 160.87 (TFA), 151.95, 147.83, 139.05, 135.91, 132.28, 124.06, 123.51, 121.15, 120.12 (TFA), 117.79 (TFA), 115.47 (TFA), 113.14 (TFA), 60.25, 58.25, 47.01, 39.16, 34.75, 29.44, 27.59, 24.01, 23.82. ESI-MS: m/z $=300.1[\mathrm{M}+\mathrm{H}]^{+} ;$ESI-MS calculated for $\left[\mathrm{C}_{17} \mathrm{H}_{25} \mathrm{~N}_{5}+\mathrm{H}\right]^{+}: \mathrm{m} / \mathrm{z}=300.2$

\section{( \pm )-trans- $N$-((1H-imidazol-4-yl)methyl)- $N$ '-(picolyl)- $N, N$ '-cyclohexane-1,2-diamine}

diacetate, (H2PyCy2AI•2TFA). Pure 2a ( $0.27 \mathrm{~g}, 0.95 \mathrm{mmol}, 1$ equiv.) in $10 \mathrm{~mL} \mathrm{MeOH}$ was added $\mathrm{NaHCO}_{3}(0.24 \mathrm{~g}, 3.78 \mathrm{mmol}, 4$ equiv. $)$ and glyoxylic acid monohydrate $(0.35 \mathrm{~g}, 3.78 \mathrm{mmol}, 4$ equiv.). A batch of sodium cyanoborohydride $(0.32 \mathrm{~g}, 3.78 \mathrm{mmol}, 4$ equiv.) was added portionwise over the course of $8 \mathrm{~h}$. After stirring for $16 \mathrm{~h}$ at RT, the reaction mixture was filtered and purified by RP-HPLC using preparative method P1. RP-HPLC fractions containing pure product were freeze dried to yield $\mathrm{H}_{2}$ PyCy2AI-2TFA as a white solid $(0.24 \mathrm{~g}, 0.38 \mathrm{mmol}, 40 \%)$. $\mathrm{pH}-$ potentiometric analysis of the isolated ligand in the presence and absence of $\mathrm{Fe}^{3+}$ are consistent with four ionizable protons per mol ligand. ${ }^{1} \mathrm{H}$ NMR (500 MHZ, $\mathrm{CD}_{3} \mathrm{OD}$ with 0.5 wt. \% NaOD): $\delta 8.79(\mathrm{~s}, 1 \mathrm{H}), 8.53(\mathrm{~s}, 1 \mathrm{H}), 7.97(\mathrm{~s}, 1 \mathrm{H}), 7.68-7.43(\mathrm{~m}, 3 \mathrm{H}), 4.45(\mathrm{~m}, 2 \mathrm{H}), 4.13(\mathrm{~d}, J=13.9 \mathrm{~Hz}$, 1H), $4.08-3.79(\mathrm{~m}, 3 \mathrm{H}), 3.63-3.34(\mathrm{~m}, 3 \mathrm{H}), 3.23(\mathrm{~d}, J=10.6 \mathrm{~Hz}, 1 \mathrm{H}), 2.22(\mathrm{~d}, J=41.9 \mathrm{~Hz}$, 2H), $1.96-1.77(\mathrm{~m}, 2 \mathrm{H}), 1.59$ (d, $J=10.7 \mathrm{~Hz}, 1 \mathrm{H}), 1.50-1.31(\mathrm{~m}, 3 \mathrm{H}) .{ }^{13} \mathrm{C}$ NMR (125.7 MHZ, $\mathrm{CD}_{3} \mathrm{OD}$ with 0.5 wt. \% NaOD): $\delta$ 176.2, 171.0, 162.2 (TFA), 161.9 (TFA), 161.6 (TFA), 161.4 (TFA), 156.6, 149.0, 137.7, 136.6, 130.0, 124.9, 123.0, 120.4 (TFA), 120.1, 118.1 (TFA), 115.7 
(TFA), 113.4 (TFA), 60.5, 58.7, 58.0, 51.3, 50.7, 49.3, 49.0, 24.3, 23.9, 23.4. ESI-MS: m/z = 402.1 $[\mathrm{M}+\mathrm{H}]^{+}$; ESI-MS calculated for $\left[\mathrm{C}_{20} \mathrm{H}_{27} \mathrm{~N}_{5} \mathrm{O}_{4}+\mathrm{H}\right]^{+}: \mathrm{m} / \mathrm{z}=402.2$.

( \pm )-trans- $N$-((1-methyl-1H-imidazol-4-yl)methyl)- $N$ '-(picolyl)- $N, N$ '-cyclohexane-1,2-

diamine diacetate, (H2PyCy2AI-Me). Pure $2 \mathbf{b}(0.29 \mathrm{~g}, 0.69 \mathrm{mmol}, 1$ equiv.) in $10 \mathrm{~mL} \mathrm{MeOH}$ was added $\mathrm{NaHCO}_{3}(0.17 \mathrm{~g}, 2.76 \mathrm{mmol}, 4$ equiv. $)$ and glyoxylic acid monohydrate $(0.25 \mathrm{~g}, 2.76$ mmol, 4 equiv.). A batch of sodium cyanoborohydride $(0.23 \mathrm{~g}, 2.76 \mathrm{mmol}, 4$ equiv.) was added portion wise over the course of $8 \mathrm{~h}$. After stirring for $16 \mathrm{~h}$ at RT, the reaction mixture was filtered and purified by RP-HPLC using preparative method P1. Preparative RP-HPLC fractions containing pure product were freeze dried to yield $\mathrm{H}_{2} \mathrm{PyCy} 2 \mathrm{CAI}-\mathrm{Me}$ as a white solid $(0.30 \mathrm{~g}, 0.57$ mmol, 83\%). ${ }^{1} \mathrm{H}$ NMR (500 MHZ, $\mathrm{CD}_{3} \mathrm{OD}$ with 0.5 wt. $\left.\% \mathrm{NaOD}\right): \delta 8.51(\mathrm{~m}, 2 \mathrm{H}), 7.87(\mathrm{t}, \mathrm{J}=$ $8.0 \mathrm{~Hz}, 1 \mathrm{H}), 7.61(\mathrm{~s}, 1 \mathrm{H}), 7.48(\mathrm{~s}, 1 \mathrm{H}), 7.42(\mathrm{~s}, 1 \mathrm{H}), 4.36(\mathrm{~s}, 2 \mathrm{H}), 4.11(\mathrm{~d}, \mathrm{~J}=14.0 \mathrm{~Hz}, 2 \mathrm{H}), 3.88$ (m, 4H), $3.74-3.34(\mathrm{~m}, 4 \mathrm{H}), 3.34-3.06(\mathrm{~m}, 2 \mathrm{H}), 2.40-2.05(\mathrm{~m}, 2 \mathrm{H}), 1.93-1.81(\mathrm{~m}, 2 \mathrm{H}), 1.62-$ $1.26(\mathrm{~m}, 2 \mathrm{H}) .{ }^{13} \mathrm{C} \mathrm{NMR}\left(125.7 \mathrm{MHZ}, \mathrm{CD}_{3} \mathrm{OD}\right.$ with 0.5 wt. \% NaOD): $\delta 172.87,169.54,161.81$ (TFA), 161.53 (TFA), 161.25 (TFA), 160.97 (TFA), 150.74, 148.09, 139.05, 136.14, 130.90, 124.83, 124.46, 122.48, 120.29 (TFA), 117.95 (TFA), 115.63 (TFA), 113.30 (TFA), 64.09, 61.53, 60.60, 55.03, 51.35, 46.72, 34.84, 24.34, 24.16, 23.96. ESI-MS: m/z = 416.1 [M+H] $]^{+}$; ESI-MS calculated for $\left[\mathrm{C}_{21} \mathrm{H}_{29} \mathrm{~N}_{5} \mathrm{O}_{4}+\mathrm{H}\right]^{+}: \mathrm{m} / \mathrm{z}=416.2$.

Fe-PyCy2AI. $\mathrm{FeCl}_{3}(23 \mathrm{mg}, 0.14 \mathrm{mmol})$ was added to a $4 \mathrm{ml}$ water solution of $\mathrm{H}_{2} \mathrm{PyCy} 2 \mathrm{AI} \cdot 2 \mathrm{TFA}$ (58 $\mathrm{mg}, 0.092 \mathrm{mmol}$ ). The $\mathrm{pH}$ was adjusted to 3.5 with $3 \mathrm{M} \mathrm{NaOH}$. Complex formation was monitored by LC-MS. The crude was filtered and subjected to preparative HPLC (method P1) purification. [Fe(HPyCy2AI)](TFA) 2 (HML) (38 $\mathrm{mg}, 0.056 \mathrm{mmol}$ and 60\%) was isolated as pure product. ESI-MS: $\mathrm{m} / \mathrm{z}=455.0[\mathrm{M}+\mathrm{H}]^{+}$; ESI-MS calculated for $\left[\mathrm{C}_{20} \mathrm{H}_{25} \mathrm{FeN}_{5} \mathrm{O}_{4}\right]^{+}: 455.1$. Elemental analysis calculated for $\mathrm{C}_{20} \mathrm{H}_{25} \mathrm{~N}_{5} \mathrm{FeO}_{4} \bullet 1.92 \mathrm{TFA} \bullet 1.20 \mathrm{H}_{2} \mathrm{O}$ : C, 41.15; H, 4.24; N, 10.06. Found: C, 41.17; H, 4.24; N, 10.06 .

Fe-PyCy2CAI-Me. $\mathrm{FeCl}_{3}(61 \mathrm{mg}, 0.76 \mathrm{mmol})$ was added to a $4 \mathrm{ml}$ water solution of $\mathrm{H}_{2} \mathrm{PyCy} 2 \mathrm{AI}-$ $\mathrm{Me}(200 \mathrm{mg}, 0.31 \mathrm{mmol}$, assuming bis-TFA adduct). $\mathrm{pH}$ was adjusted to 3.5 by adding $3 \mathrm{M} \mathrm{NaOH}$. Complex formation was monitored by LC-MS. The crude was filtered and subjected to preparative HPLC (method P1) purification. Pale yellow solid (180 mg, $0.26 \mathrm{mmol}, 83 \%$, assuming product isolated as bis-TFA adduct) was isolated as pure product. ESI-MS: m/z $=469.0[\mathrm{M}+\mathrm{H}]^{+}$; ESI-MS calculated for $\left[\mathrm{C}_{21} \mathrm{H}_{27} \mathrm{FeN}_{5} \mathrm{O}_{4}\right]^{+}: 469.1$. Elemental analysis calculated for 
$\mathrm{C}_{21} \mathrm{H}_{27} \mathrm{~N}_{5} \mathrm{FeO}_{4} \cdot 2.52 \mathrm{TFA} \cdot 0.72 \mathrm{H}_{2} \mathrm{O} \bullet 0.70 \mathrm{MeCN}: \mathrm{C}, 40.89 ; \mathrm{H}, 4.18 ; \mathrm{N}, 9.99$. Found: $\mathrm{C}, 40.78 ; \mathrm{H}$, $4.17 ; \mathrm{N}, 10.00$. 


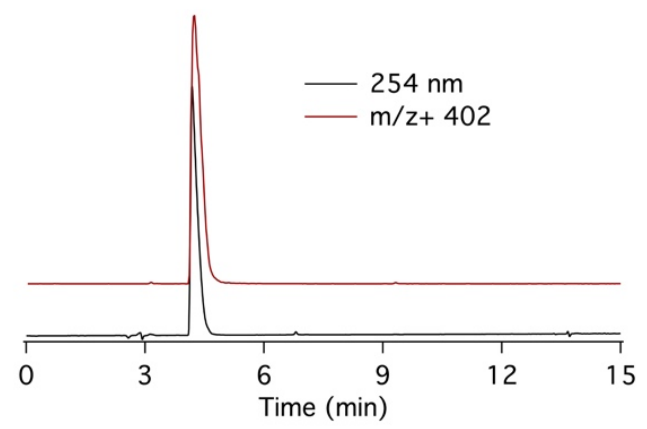

Figure S1. LC trace of PyCy2AI at $254 \mathrm{~nm}$ detection (black trace) and MS chromatogram of extracted $m / z^{+} 402$ (red trace). The LC-MS was recorded using method A1.

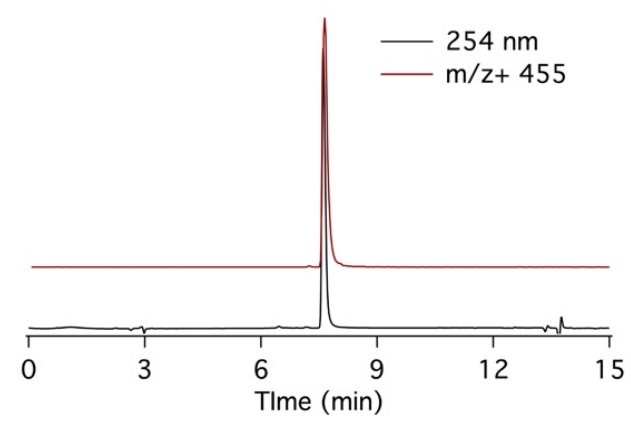

Figure S2. LC trace of isolated Fe-PyCy2AI-Me at $254 \mathrm{~nm}$ detection (black trace) and MS chromatogram of extracted $m / z^{+} 455$ (red trace). The LC-MS was recorded using method A1.

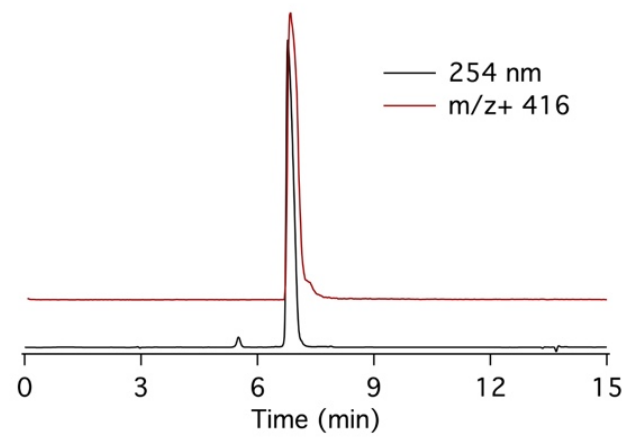

Figure S3. LC trace of PyCy2AI-Me at $254 \mathrm{~nm}$ detection (black trace) and MS chromatogram of extracted $m / z^{+} 416$ (red trace). The LC-MS was recorded using method A1. 


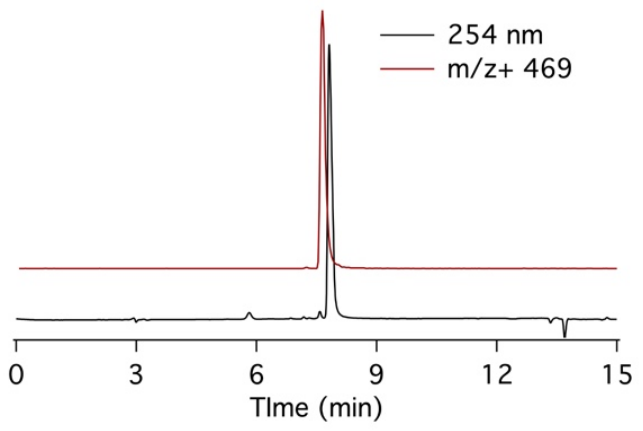

Figure S4. LC trace of PyCy2AI-Me at $254 \mathrm{~nm}$ detection (black trace) and MS chromatogram of extracted $m / z^{+} 469$ (red trace). The LC-MS was recorded using method A1
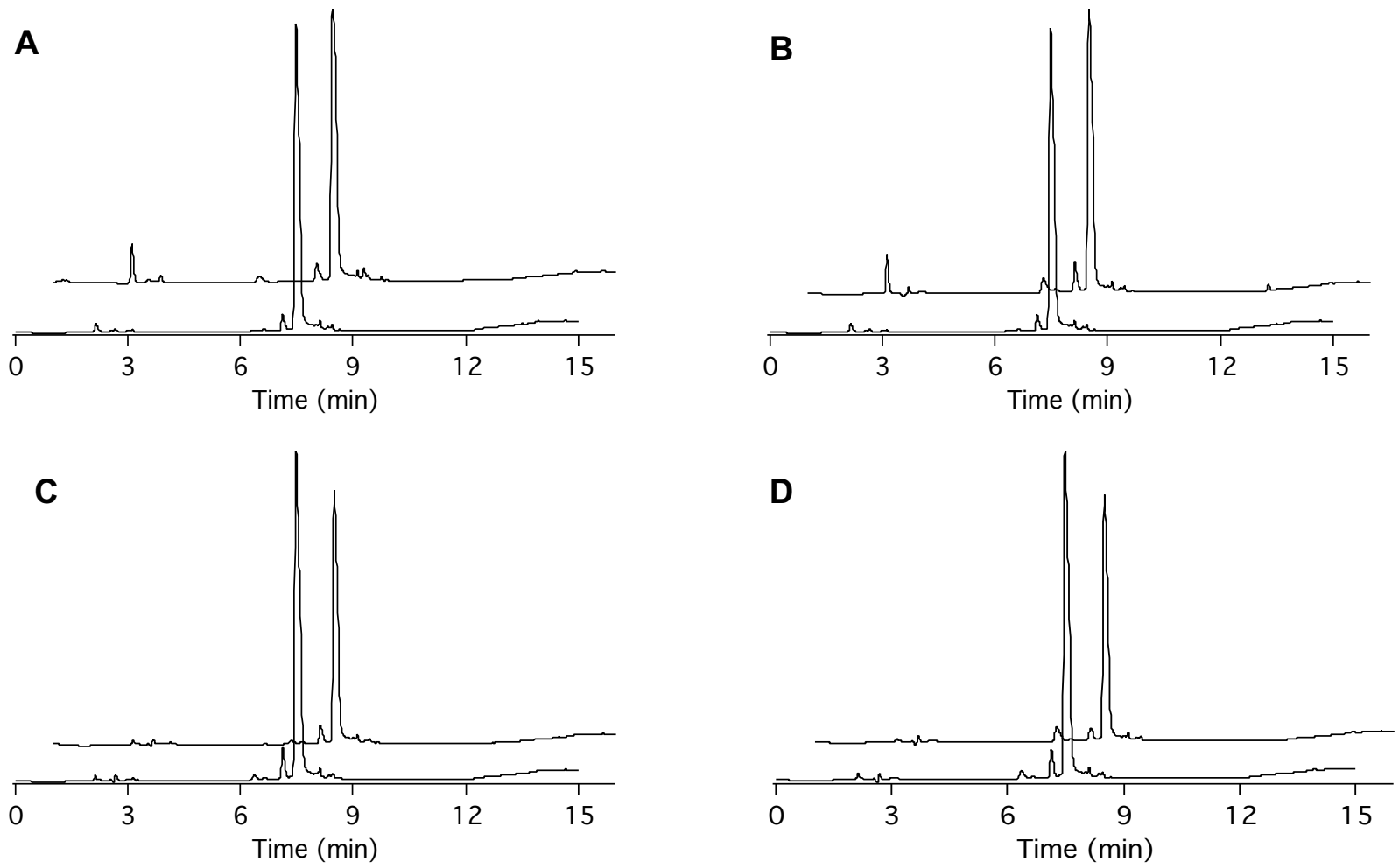

Figure S5. HPLC trace of Fe-PyCy2AI at $254 \mathrm{~nm}$ detection recorded within $30 \mathrm{~min}$ (front trace) and 24 hours after (offset trace) of dissolution in buffered solutions of $\mathrm{pH} 4.2$ (A, $100 \mathrm{mM}$ phosphate), pH 7.4 (B, $100 \mathrm{mM}$ phosphate), 9.0 (C, $100 \mathrm{mM}$ borate), and 11.2 (D, $100 \mathrm{mM}$ borate). The HPLC data were recorded using method A1. 


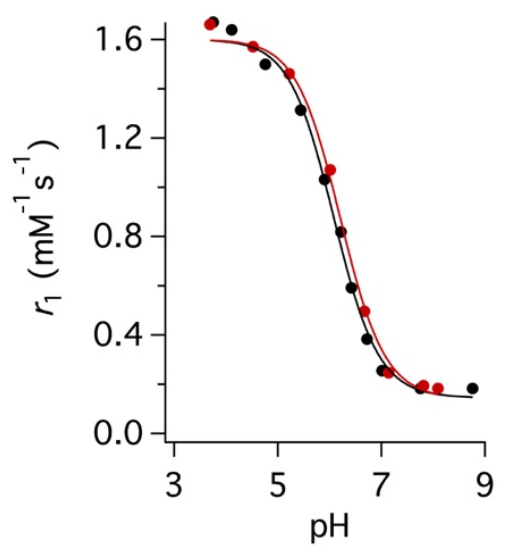

Figure S6. Plots of $\mathrm{r}_{1}$ vs. $\mathrm{pH}$ of $7.0 \mathrm{mM}$ Fe-PyCy2AI as $\mathrm{pH}$ is increased from $\mathrm{pH} 3.8$ to $\mathrm{pH} 8.8$ (black trace), and then titrated in the reverse direction (red trace) demonstrate that $\mathrm{pH}$-dependence on $r_{1}$ is governed by an equilibrium mixture of Fe species.

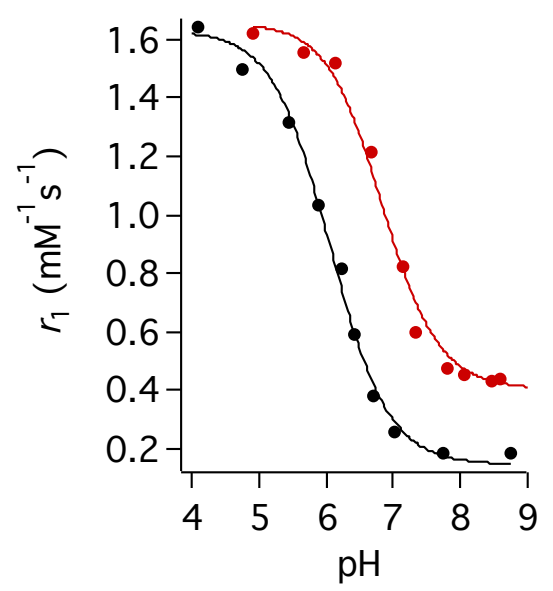

Figure S7. Plots of $\mathrm{r}_{1}$ vs. $\mathrm{pH}$ of $7.0 \mathrm{mM}$ (black) and $0.5 \mathrm{mM}$ (red) solutions of Fe-PyCy2AI demonstrates concentration dependence on apparent $\mathrm{pK}_{\mathrm{a}}$ of water co-ligand. 


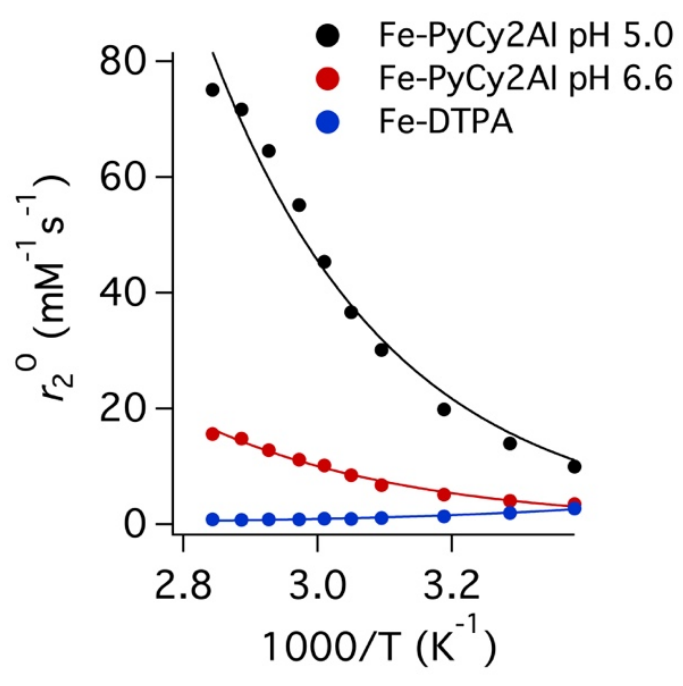

Figure S8. Comparison of temperature dependence on $\mathrm{T}_{2}$-relaxivity of water ${ }^{17} \mathrm{O}\left(\mathrm{r}_{2}{ }^{\mathrm{O}}\right)$ in the presence of Fe-PyCy2AI at pH 5.0 and $\mathrm{pH} 6.6$ and the $q=0$ complex Fe-DTPA recorded at $\mathrm{pH}$ 7.4.

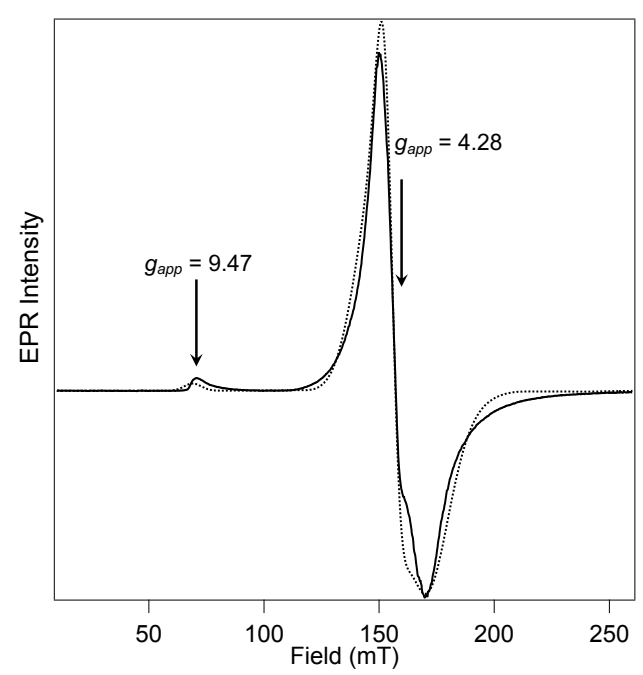

Figure S9. CW EPR spectra recorded with $1 \mathrm{mM}$ concentration of Fe-PyCy2AI at $\mathrm{T}=10 \mathrm{~K}$ and $\mathrm{P}_{\mu \mathrm{w}}=0.2 \mathrm{~mW}$ at $\mathrm{pH}$ 4.2. Dotted line represents major component of simulation with with $\mathrm{E} / \mathrm{D}=$ 0.28. $\mathrm{g}=1.95 \mathrm{~g}=2.06 \mathrm{~g}=1.99 \mathrm{D}=3.7 \mathrm{~cm}^{-1} \mathrm{E}=.94 \mathrm{~cm}^{-1} \mathrm{E} / \mathrm{D}=.25$ 

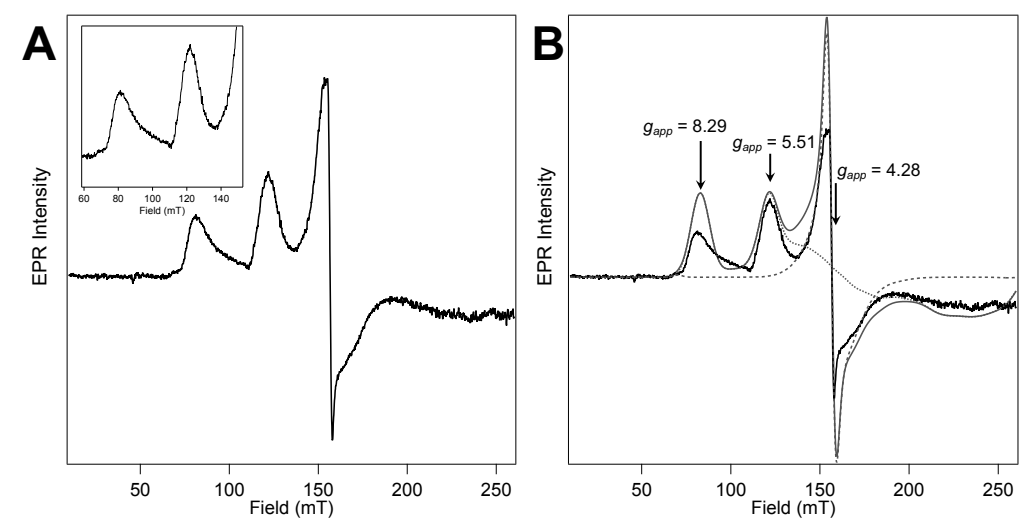

Figure S10. (A) CW X-band EPR spectra recorded with $1 \mathrm{mM}$ concentration of Fe-PyCy2AI at $\mathrm{T}=10 \mathrm{~K}$ and $\mathrm{P}_{\mu \mathrm{w}}=0.2 \mathrm{~mW}$ at $\mathrm{pH}$ 9.0. Inset: Low field region of reported spectra. (B) Experimental data (black line) overlaid with the total simulation (gray line) for $\mathrm{pH}=9.0$. Dotted line represents major component of simulation with an $\mathrm{E} / \mathrm{D}=0.11$, dashed line represents minor component of simulation with $\mathrm{E} / \mathrm{D}=0.28 \mathrm{~g}=1.95 \mathrm{~g}=1.98 \mathrm{~g}=2.03 \mathrm{D}=.66 \mathrm{~cm}^{-1} \mathrm{E}=.19 \mathrm{~cm}^{-1} \mathrm{E} / \mathrm{D}=.2810 \%$ $\mathrm{g}=2.30 \mathrm{~g}=2.00 \mathrm{~g}=1.95 \mathrm{D}=1.38 \mathrm{~cm}^{-1} \mathrm{E}=.15 \mathrm{~cm}^{-1} \mathrm{E} / \mathrm{D}=1190 \%$.
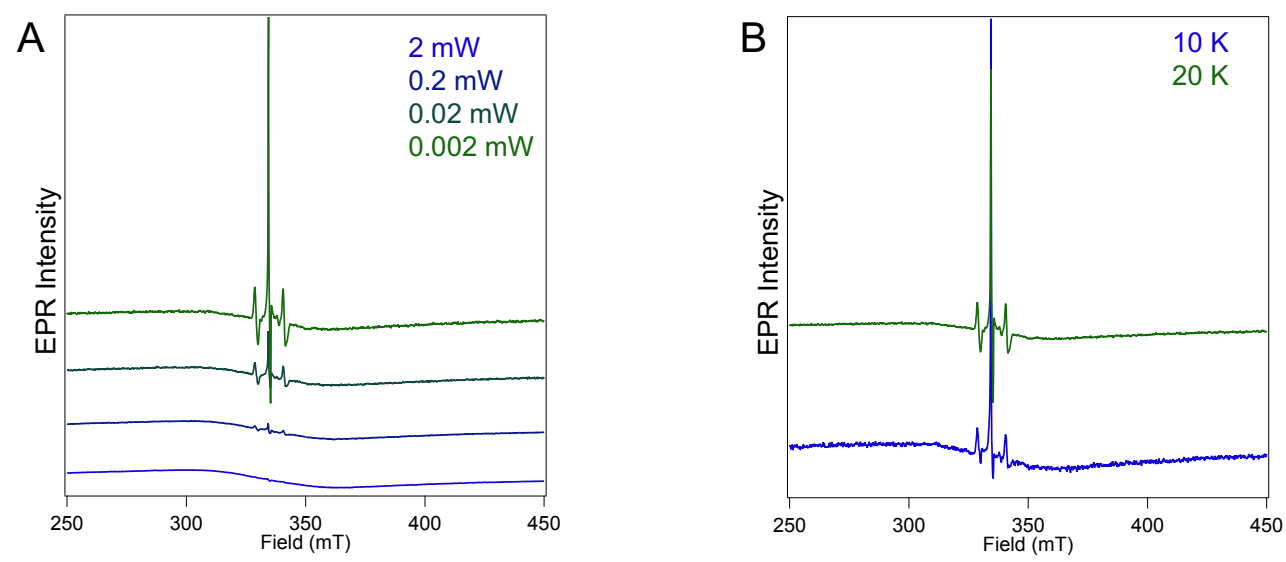

Figure S11. (A) High field Power Dependence of Fe-PyCy2AI at $\mathrm{pH}=7.0$. CW X-band EPR spectra were recorded at $\mathrm{T}=20 \mathrm{~K}$, and a concentration of $1 \mathrm{mM}$. Spectra offset for clarity. (B) High field CW X-band EPR Spectra of $1 \mathrm{mM}$ Fe-PyCy2AI at $\mathrm{pH}=7.0$ at $\mathrm{P}_{\mu \mathrm{w}}=0.002 \mathrm{~mW}$ and designated temperatures. Spectra offset for clarity. 

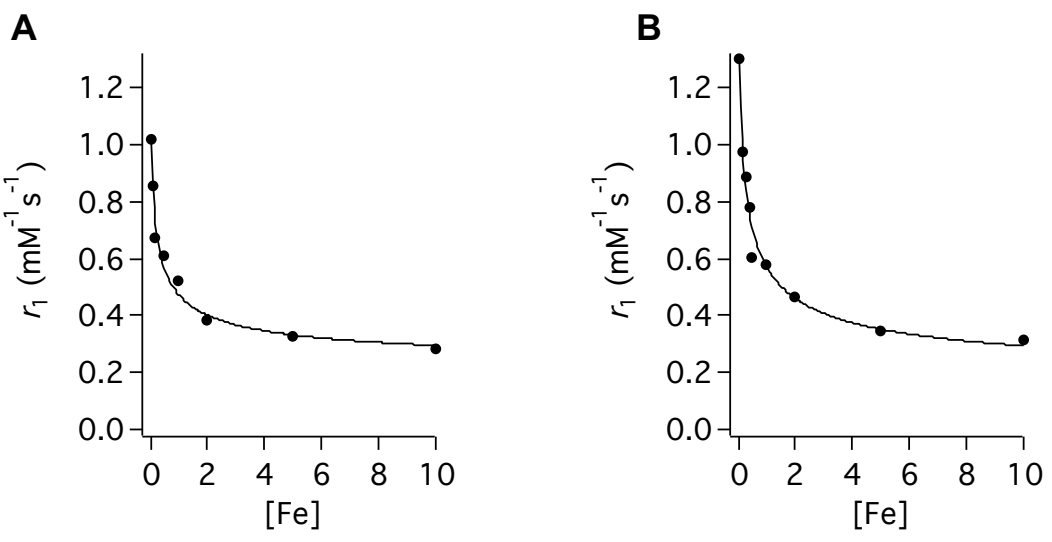

Figure S12. Concentration dependence of Fe-PyCy2AI $r_{1}$ at $\mathrm{pH} 9.0,4.7 \mathrm{~T}(\mathrm{~A})$ and 11.7T (B), 310K.
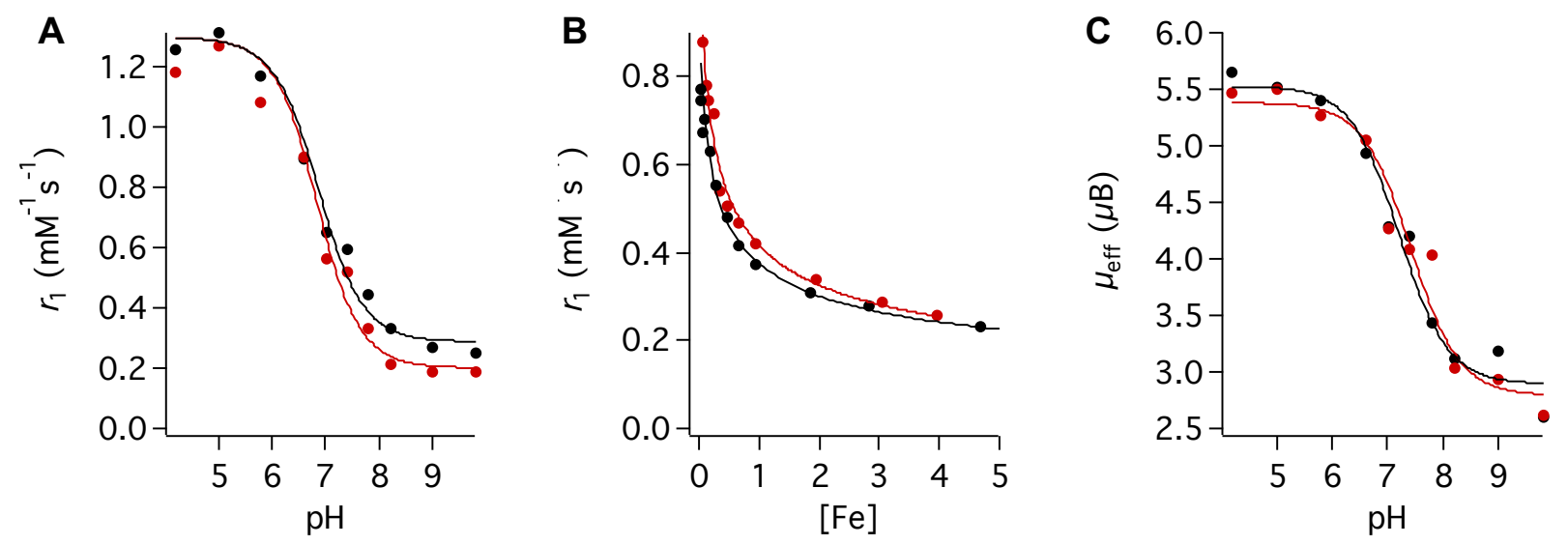

Figure S13. (A) Comparison of pH-dependence on $\mathrm{r}_{1} 10 \mathrm{mM}$ Fe-PyCy2AI (black circles) and 10 $\mathrm{mM}$ Fe-PyCy2AI-Me (red circles) at $310 \mathrm{~K}$ and $1.4 \mathrm{~T}$. (B) (A) Concentration dependence on $\mathrm{r}_{1}$ of Fe-PyCy2AI (black circles) and Fe-PyCy2AI-Me (red circles) at 310K and 1.4T. (C) Comparison of bulk magnetic susceptibility dependence on pH of $10 \mathrm{mM}$ Fe-PyCy2AI (black circles) and 10 mM Fe-PyCy2AI-Me (red circles) at 310K. 

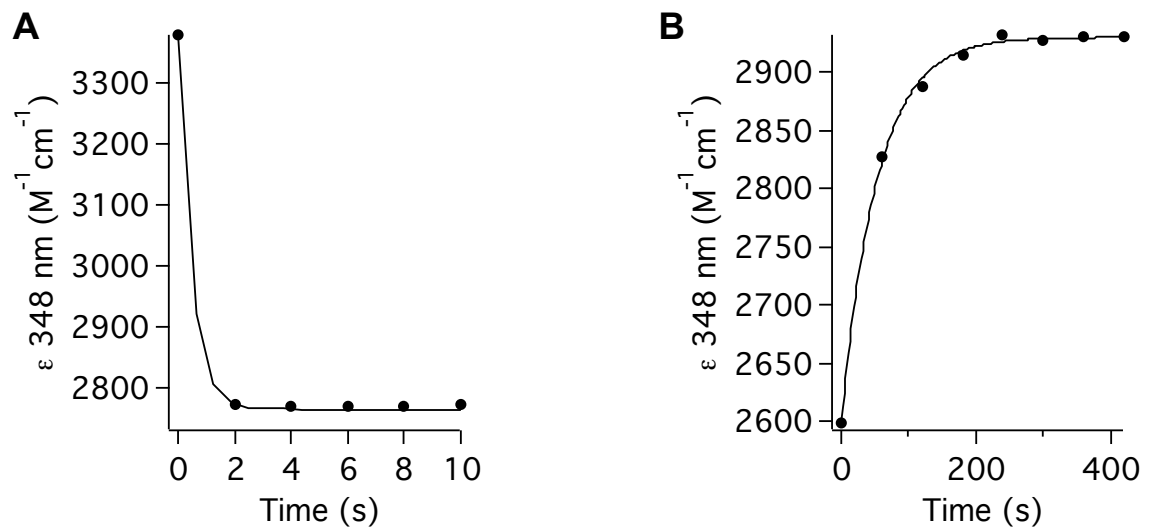

Figure S14. (A) change in UV-vis absorbance at $348 \mathrm{~nm}$ after diluting a $5.0 \mathrm{mM}$ aliquot of $\mathrm{pH} 7.4$ solution (100 mM Tris) of Fe-PyCy2AI to $0.5 \mathrm{mM}$ in pH 6.0 buffer at $310 \mathrm{~K}$. (B) change in UVvis absorbance at $348 \mathrm{~nm}$ after diluting $5.0 \mathrm{mM}$ aliquot of $\mathrm{pH} 6.0$ solution of $5.0 \mathrm{mM}$ Fe-PyCy2AI to $0.5 \mathrm{mM}$ in $\mathrm{pH} 9.0$ buffer ( $100 \mathrm{mM}$ borate) at $310 \mathrm{~K}$.
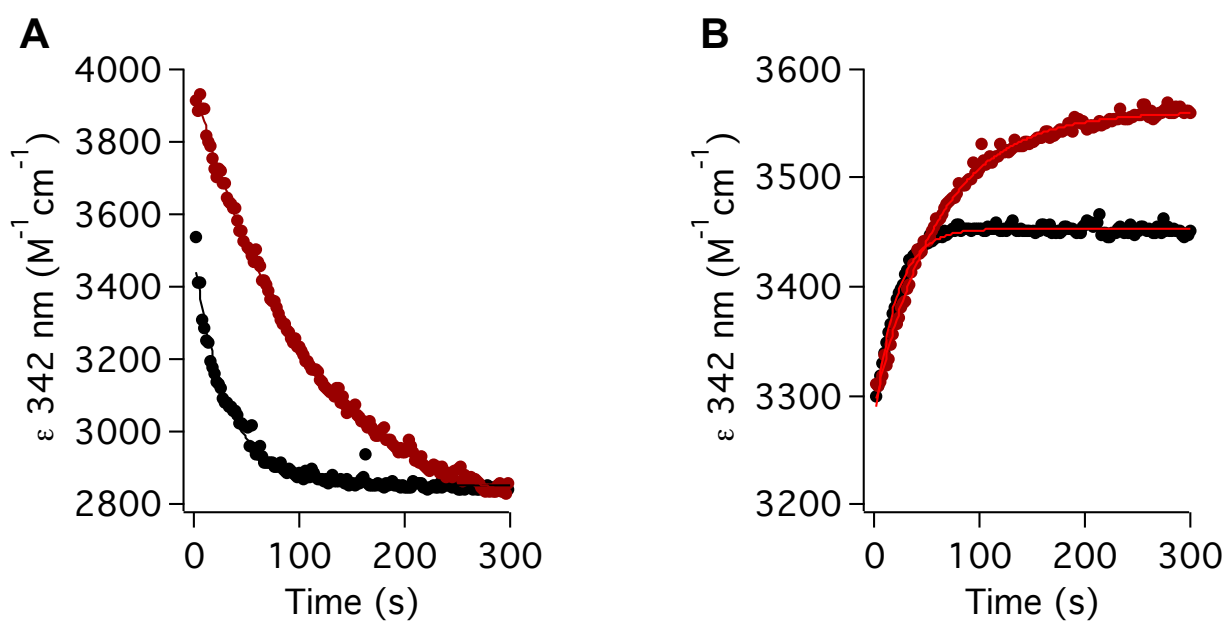

Figure S15. (A) change in UV-vis absorbance at $348 \mathrm{~nm}$ after diluting a $5.0 \mathrm{mM}$ aliquot of $\mathrm{pH} 9.0$ Fe-PyCy2AI solution to $0.1 \mathrm{mM}$ in $\mathrm{pH} 8.0$ (black) or $\mathrm{pH} 9.0$ (red) buffered solutions (100 mM borate) at $310 \mathrm{~K}$. (B) (A) change in UV-vis absorbance at $348 \mathrm{~nm}$ after adding $5.0 \mathrm{mM}$ aliquot of pH 5.0 solution of $0.1 \mathrm{mM} \mathrm{Fe-PyCy2AI} \mathrm{to} \mathrm{pH} 8.5$ or $\mathrm{pH} 9.0$ buffered solutions (100 mM borate) at $310 \mathrm{~K}$. 
Table 1. Crystal data for complex $(\mathbf{M L})_{2} \mathbf{O}$.

\begin{tabular}{|l|l|}
\hline $\mathrm{C}_{40} \mathrm{H}_{50} \mathrm{Fe}_{2} \mathrm{~N}_{10} \mathrm{O}_{9} \cdot 6\left(\mathrm{H}_{2} \mathrm{O}\right)$ & $F(000)=1208$ \\
\hline$M_{r}=1142.79$ & $D_{\mathrm{x}}=1.465 \mathrm{Mg} \mathrm{m}^{-3}$ \\
\hline Monoclinic, $P 2 / c$ & $\mathrm{Cu} K \alpha$ radiation, $\lambda=1.54178 \AA$ \\
\hline$a=11.9411(9) \AA$ & Cell parameters from 9303 reflections \\
\hline$b=9.7448(7) \AA$ & $\theta=6.0-66.6^{\circ}$ \\
\hline$c=22.2881(17) \AA$ & $\mu=5.23 \mathrm{~mm}^{-1}$ \\
\hline$\beta=92.422(3)^{\circ}$ & $T=100 \mathrm{~K}$ \\
\hline$V=2591.2(3) \AA^{3}$ & Block, orange \\
\hline$Z=2$ & $0.29 \times 0.22 \times 0.12 \mathrm{~mm}$ \\
\hline
\end{tabular}

Table 2. X-ray data collection parameters for complex (ML) $)_{2} \mathbf{O}$.

\begin{tabular}{|l|l|}
\hline $\begin{array}{l}\text { Bruker X8 Proteum-R } \\
\text { diffractometer }\end{array}$ & 4586 independent reflections \\
\hline Radiation source: rotating anode & 4562 reflections with $I>2 \sigma(I)$ \\
\hline Montel monochromator & $R_{\text {int }}=0.043$ \\
\hline$\phi$ and $\omega$ scans & $\theta_{\max }=66.7^{\circ}, \theta_{\min }=5.0^{\circ}$ \\
\hline $\begin{array}{l}\text { Absorption correction: multi-scan } \\
S A D A B S 2016 / 2 \text { (Bruker, 2016/2) was used for } \\
\text { absorption correction. wR2(int) was } 0.1079 \\
\text { before and } 0.0619 \text { after correction. The Ratio of } \\
\text { minimum to maximum transmission is } 0.7885 . \\
\text { The } \lambda / 2 \text { correction factor is Not present. }\end{array}$ & $h=-14 \rightarrow 14$ \\
\hline$T_{\min }=0.594, T_{\max }=0.753$ & $k=-11 \rightarrow 11$ \\
\hline 90513 measured reflections & $l=-26 \rightarrow 26$ \\
\hline
\end{tabular}


Table 3. Crystal structure refinement of complex $(\mathbf{M L})_{2} \mathbf{O}$.

\begin{tabular}{|l|l|}
\hline Refinement on $F^{2}$ & Primary atom site location: dual \\
\hline Least-squares matrix: full & Hydrogen site location: mixed \\
\hline$R\left[F^{2}>2 \sigma\left(F^{2}\right)\right]=0.031$ & $\begin{array}{l}\text { H atoms treated by a mixture of independent } \\
\text { and constrained refinement }\end{array}$ \\
\hline$w R\left(F^{2}\right)=0.082$ & $\begin{array}{l}w=1 /\left[\sigma^{2}\left(F_{\mathrm{o}}^{2}\right)+(0.0447 P)^{2}+1.8917 P\right] \\
\text { where } P=\left(F_{\mathrm{o}}^{2}+2 F_{\mathrm{c}}^{2}\right) / 3\end{array}$ \\
\hline$S=1.08$ & $(\Delta / \sigma)_{\max }=0.002$ \\
\hline 4586 reflections & $\Delta\rangle_{\max }=0.78$ e $\AA^{-3}$ \\
\hline 359 parameters & $\Delta\rangle_{\min }=-0.34$ e $\AA^{-3}$ \\
\hline 0 restraints & \\
\hline Special details & \\
\hline $\begin{array}{l}\text { Geometry. All esds (except the esd in the dihedral angle between two l.s. planes) are estimated } \\
\text { using the full covariance matrix. The cell esds are taken into account individually in the } \\
\text { estimation of esds in distances, angles and torsion angles; correlations between esds in cell } \\
\text { parameters are only used when they are defined by crystal symmetry. An approximate (isotropic) } \\
\text { treatment of cell esds is used for estimating esds involving l.s. planes. }\end{array}$ \\
\hline
\end{tabular}




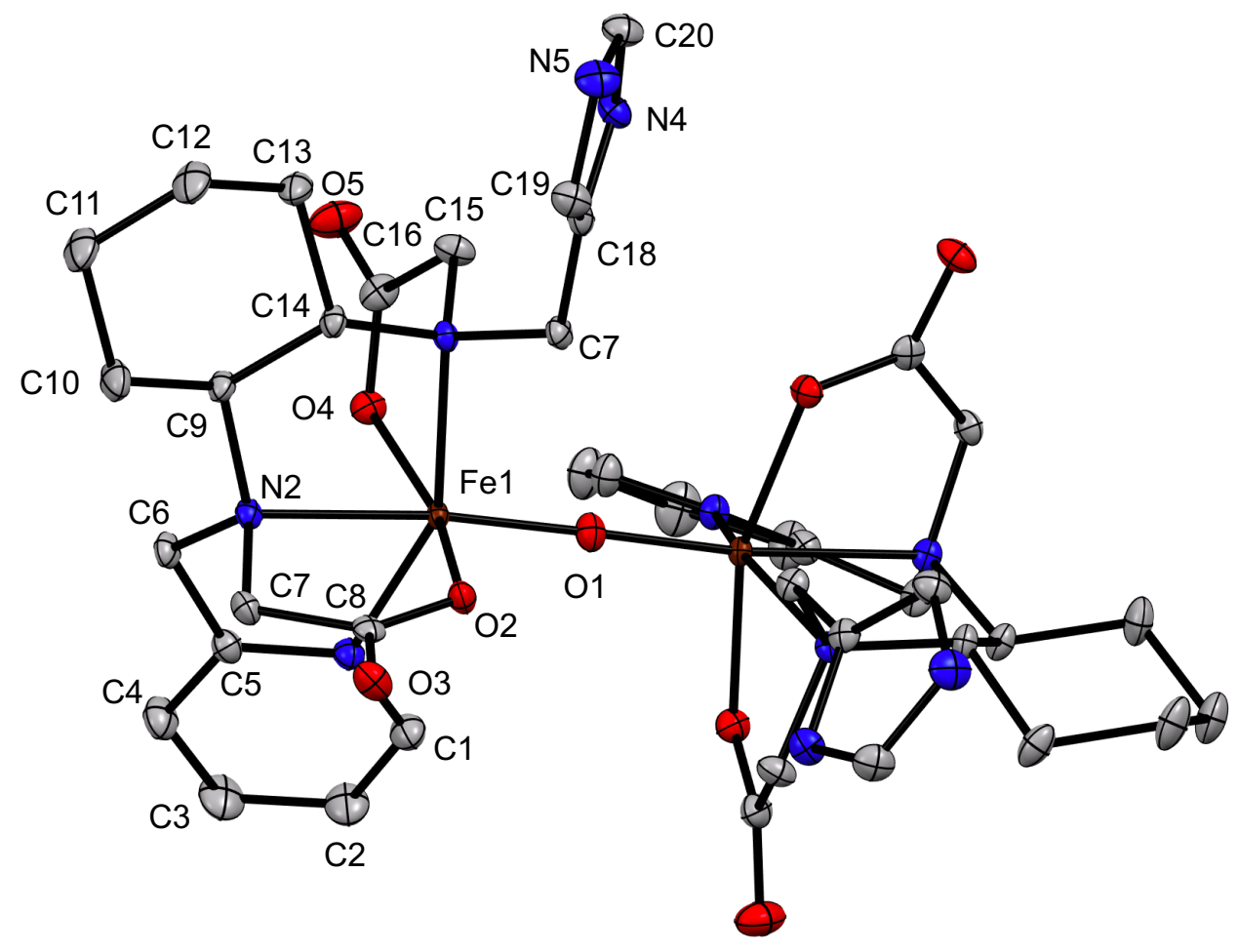

Figure S16. ORTEP diagram of (ML) $)_{2} \mathbf{O}$ showing 50\% thermal probability ellipsoids for all non-H atoms. Water solvent molecules omitted for clarity. Labelled non-H atoms guide reading of Table 4.

Table 4. Geometric parameters for $(\mathbf{M L})_{2} \mathbf{O}$ crystal structure.

\begin{tabular}{|l|l|l|l|}
\hline $\mathrm{Fe} 1-\mathrm{O} 4$ & $2.0335(12)$ & $\mathrm{N} 2-\mathrm{C} 7$ & $1.476(2)$ \\
\hline $\mathrm{Fe} 1-\mathrm{O} 2$ & $2.0332(12)$ & $\mathrm{N} 5-\mathrm{C} 19$ & $1.371(2)$ \\
\hline $\mathrm{Fe} 1-\mathrm{O} 1$ & $1.7791(3)$ & $\mathrm{N} 5-\mathrm{C} 20$ & $1.341(2)$ \\
\hline $\mathrm{Fe} 1-\mathrm{N} 3$ & $2.2089(13)$ & $\mathrm{C} 14-\mathrm{C} 9$ & $1.542(2)$ \\
\hline $\mathrm{Fe} 1-\mathrm{N} 1$ & $2.1295(14)$ & $\mathrm{C} 14-\mathrm{C} 13$ & $1.541(2)$ \\
\hline $\mathrm{Fe} 1-\mathrm{N} 2$ & $2.2229(14)$ & $\mathrm{C} 17-\mathrm{C} 18$ & $1.493(2)$ \\
\hline $\mathrm{O} 4-\mathrm{C} 16$ & $1.278(2)$ & $\mathrm{C} 19-\mathrm{C} 18$ & $1.367(2)$ \\
\hline $\mathrm{O} 2-\mathrm{C} 8$ & $1.275(2)$ & $\mathrm{C} 9-\mathrm{C} 10$ & $1.536(2)$ \\
\hline $\mathrm{O} 3-\mathrm{C} 8$ & $1.242(2)$ & $\mathrm{C} 16-\mathrm{C} 15$ & $1.524(2)$ \\
\hline $\mathrm{O} 5-\mathrm{C} 16$ & $1.231(2)$ & $\mathrm{C} 8-\mathrm{C} 7$ & $1.516(2)$ \\
\hline $\mathrm{N} 3-\mathrm{C} 14$ & $1.5084(19)$ & $\mathrm{C} 5-\mathrm{C} 6$ & $1.507(2)$ \\
\hline $\mathrm{N} 3-\mathrm{C} 17$ & $1.506(2)$ & $\mathrm{C} 5-\mathrm{C} 4$ & $1.384(2)$ \\
\hline $\mathrm{N} 3-\mathrm{C} 15$ & $1.488(2)$ & $\mathrm{C} 1-\mathrm{C} 2$ & $1.377(3)$ \\
\hline
\end{tabular}




\begin{tabular}{|c|c|c|c|}
\hline $\mathrm{N} 1-\mathrm{C} 5$ & $1.346(2)$ & $\mathrm{C} 10-\mathrm{C} 11$ & $1.526(2)$ \\
\hline $\mathrm{N} 1-\mathrm{C} 1$ & $1.346(2)$ & $\mathrm{C} 13-\mathrm{C} 12$ & $1.528(2)$ \\
\hline $\mathrm{N} 4-\mathrm{C} 18$ & $1.390(2)$ & $\mathrm{C} 12-\mathrm{C} 11$ & $1.517(3)$ \\
\hline $\mathrm{N} 4-\mathrm{C} 20$ & $1.324(2)$ & $\mathrm{C} 4-\mathrm{C} 3$ & $1.387(3)$ \\
\hline $\mathrm{N} 2-\mathrm{C} 9$ & $1.505(2)$ & $\mathrm{C} 3-\mathrm{C} 2$ & $1.381(3)$ \\
\hline $\mathrm{N} 2-\mathrm{C} 6$ & $1.485(2)$ & & \\
\hline $\mathrm{O} 4-\mathrm{Fe} 1-\mathrm{N} 3$ & $79.46(5)$ & $\mathrm{C} 20-\mathrm{N} 5-\mathrm{C} 19$ & $107.16(14)$ \\
\hline $\mathrm{O} 4-\mathrm{Fe} 1-\mathrm{N} 1$ & $82.52(5)$ & N3-C14-C9 & $112.79(12)$ \\
\hline $\mathrm{O} 4-\mathrm{Fe} 1-\mathrm{N} 2$ & $84.06(5)$ & $\mathrm{N} 3-\mathrm{C} 14-\mathrm{C} 13$ & $114.70(13)$ \\
\hline $\mathrm{O} 2-\mathrm{Fe} 1-\mathrm{O} 4$ & $161.06(5)$ & $\mathrm{C} 13-\mathrm{C} 14-\mathrm{C} 9$ & $107.02(13)$ \\
\hline $\mathrm{O} 2-\mathrm{Fe} 1-\mathrm{N} 3$ & $89.59(5)$ & $\mathrm{C} 18-\mathrm{C} 17-\mathrm{N} 3$ & $116.11(13)$ \\
\hline $\mathrm{O} 2-\mathrm{Fe} 1-\mathrm{N} 1$ & $101.80(5)$ & $\mathrm{C} 18-\mathrm{C} 19-\mathrm{N} 5$ & $106.44(15)$ \\
\hline $\mathrm{O} 2-\mathrm{Fe} 1-\mathrm{N} 2$ & $79.20(5)$ & $\mathrm{N} 4-\mathrm{C} 18-\mathrm{C} 17$ & $122.14(14)$ \\
\hline $\mathrm{O} 1-\mathrm{Fe} 1-\mathrm{O} 4$ & $101.02(5)$ & $\mathrm{C} 19-\mathrm{C} 18-\mathrm{N} 4$ & $109.21(14)$ \\
\hline $\mathrm{O} 1-\mathrm{Fe} 1-\mathrm{O} 2$ & $96.25(5)$ & $\mathrm{C} 19-\mathrm{C} 18-\mathrm{C} 17$ & $128.65(15)$ \\
\hline $\mathrm{O} 1-\mathrm{Fe} 1-\mathrm{N} 3$ & $101.43(5)$ & $\mathrm{N} 2-\mathrm{C} 9-\mathrm{C} 14$ & $113.04(13)$ \\
\hline $\mathrm{O} 1-\mathrm{Fe} 1-\mathrm{N} 1$ & $101.19(6)$ & $\mathrm{N} 2-\mathrm{C} 9-\mathrm{C} 10$ & $112.98(14)$ \\
\hline $\mathrm{O} 1-\mathrm{Fe} 1-\mathrm{N} 2$ & $173.98(4)$ & $\mathrm{C} 10-\mathrm{C} 9-\mathrm{C} 14$ & $109.69(13)$ \\
\hline $\mathrm{N} 3-\mathrm{Fe} 1-\mathrm{N} 2$ & $82.59(5)$ & $\mathrm{O} 4-\mathrm{C} 16-\mathrm{C} 15$ & $115.74(14)$ \\
\hline $\mathrm{N} 1-\mathrm{Fe} 1-\mathrm{N} 3$ & $153.33(5)$ & $\mathrm{O} 5-\mathrm{C} 16-\mathrm{O} 4$ & $123.19(16)$ \\
\hline $\mathrm{N} 1-\mathrm{Fe} 1-\mathrm{N} 2$ & $76.11(5)$ & $\mathrm{O} 5-\mathrm{C} 16-\mathrm{C} 15$ & $121.04(15)$ \\
\hline $\mathrm{C} 16-\mathrm{O} 4-\mathrm{Fe} 1$ & $118.12(10)$ & $\mathrm{O} 2-\mathrm{C} 8-\mathrm{C} 7$ & $116.89(14)$ \\
\hline $\mathrm{C} 8-\mathrm{O} 2-\mathrm{Fe} 1$ & $118.98(10)$ & $\mathrm{O} 3-\mathrm{C} 8-\mathrm{O} 2$ & $124.51(15)$ \\
\hline $\mathrm{Fe} 1{ }^{\mathrm{i}}-\mathrm{O} 1-\mathrm{Fe} 1$ & $177.38(10)$ & $\mathrm{O} 3-\mathrm{C} 8-\mathrm{C} 7$ & $118.51(14)$ \\
\hline $\mathrm{C} 14-\mathrm{N} 3-\mathrm{Fe} 1$ & $108.51(9)$ & $\mathrm{N} 1-\mathrm{C} 5-\mathrm{C} 6$ & $116.90(14)$ \\
\hline $\mathrm{C} 17-\mathrm{N} 3-\mathrm{Fe} 1$ & $107.85(9)$ & $\mathrm{N} 1-\mathrm{C} 5-\mathrm{C} 4$ & $121.24(16)$ \\
\hline $\mathrm{C} 17-\mathrm{N} 3-\mathrm{C} 14$ & $111.47(12)$ & $\mathrm{C} 4-\mathrm{C} 5-\mathrm{C} 6$ & $121.73(15)$ \\
\hline $\mathrm{C} 15-\mathrm{N} 3-\mathrm{Fe} 1$ & $103.23(9)$ & $\mathrm{N} 1-\mathrm{C} 1-\mathrm{C} 2$ & $121.91(16)$ \\
\hline $\mathrm{C} 15-\mathrm{N} 3-\mathrm{C} 14$ & $114.44(13)$ & $\mathrm{N} 2-\mathrm{C} 6-\mathrm{C} 5$ & $110.39(13)$ \\
\hline $\mathrm{C} 15-\mathrm{N} 3-\mathrm{C} 17$ & $110.80(12)$ & $\mathrm{C} 11-\mathrm{C} 10-\mathrm{C} 9$ & $111.98(15)$ \\
\hline $\mathrm{C} 5-\mathrm{N} 1-\mathrm{Fe} 1$ & $115.94(11)$ & $\mathrm{N} 2-\mathrm{C} 7-\mathrm{C} 8$ & $112.83(13)$ \\
\hline $\mathrm{C} 1-\mathrm{N} 1-\mathrm{Fe} 1$ & $123.49(11)$ & $\mathrm{C} 12-\mathrm{C} 13-\mathrm{C} 14$ & $110.70(14)$ \\
\hline $\mathrm{C} 1-\mathrm{N} 1-\mathrm{C} 5$ & $119.45(14)$ & $\mathrm{N} 3-\mathrm{C} 15-\mathrm{C} 16$ & $111.39(13)$ \\
\hline $\mathrm{C} 20-\mathrm{N} 4-\mathrm{C} 18$ & $105.00(14)$ & $\mathrm{N} 4-\mathrm{C} 20-\mathrm{N} 5$ & $112.18(15)$ \\
\hline $\mathrm{C} 9-\mathrm{N} 2-\mathrm{Fe} 1$ & $107.58(9)$ & $\mathrm{C} 11-\mathrm{C} 12-\mathrm{C} 13$ & $110.51(15)$ \\
\hline $\mathrm{C} 6-\mathrm{N} 2-\mathrm{Fe} 1$ & $107.42(9)$ & $\mathrm{C} 5-\mathrm{C} 4-\mathrm{C} 3$ & $119.17(17)$ \\
\hline
\end{tabular}




\begin{tabular}{|l|l|l|l|}
\hline $\mathrm{C} 6-\mathrm{N} 2-\mathrm{C} 9$ & $111.10(13)$ & $\mathrm{C} 12-\mathrm{C} 11-\mathrm{C} 10$ & $110.03(15)$ \\
\hline $\mathrm{C} 7-\mathrm{N} 2-\mathrm{Fe} 1$ & $105.47(9)$ & $\mathrm{C} 2-\mathrm{C} 3-\mathrm{C} 4$ & $119.22(17)$ \\
\hline $\mathrm{C} 7-\mathrm{N} 2-\mathrm{C} 9$ & $115.71(12)$ & $\mathrm{C} 1-\mathrm{C} 2-\mathrm{C} 3$ & $118.98(17)$ \\
\hline $\mathrm{C} 7-\mathrm{N} 2-\mathrm{C} 6$ & $109.10(13)$ & & \\
\hline
\end{tabular}




\section{References.}

1. Fulmer, G. R.; Miller, A. J. M.; Sherden, N. H.; Gottlieb, H. E.; Nudelman, A.; Stoltz, B. M.; Bercaw, J. E.; Goldberg, K. I., NMR Chemical Shifts of Trace Impurities: Common Laboratory Solvents, Organics, and Gases in Deuterated Solvents Relevant to the Organometallic Chemist. Organometallics 2010, 29 (9), 2176-2179.

2. Swift, T. J.; Connick, R. E., NMR-Relaxation Mechanisms of O17 in Aqueous Solutions of Paramagnetic Cations and the LIfetime of Water Molecules in the First Coordination Sphere. J. Chem. Phys. 1962, 37 (2), 307-320.

3. Maigut, J.; Meier, R.; Zahl, A.; van Eldik, R., Effect of chelate dynamics on water exchange reactions of paramagnetic aminopolycarboxylate complexes. Inorg. Chem. 2008, 47 (13), 5702-5719.

4. Maigut, J.; Meier, R.; Zahl, A.; van Eldik, R., Triggering Water Exchange Mechanisms via Chelate Architecture. Shielding of Transition Metal Centers by Aminopolycarboxylate Spectator Ligands. J. Am. Chem. Soc. 2008, 130, 14556-14569.

5. Wang, H.; Clavijo Jordan, V.; Ramsay, I. A.; Sojoodi, M.; Fuchs, B. C.; Tanabe, K. K.; Caravan, P.; Gale, E. M., Molecular Magnetic Resonance Imaging Using a Redox-Active Iron Complex. J. Am. Chem. Soc. 2019, 141 (14), 5916-5925.

6. Gans, P.; Sabatini, A.; Vacca, A., Investigation of equilibria in solution. Determination of equilibrium constants with the HYPERQUAD suite of programs. Talanta 1996, 43, 1739-1753.

7. Evans, D. F., 400. The determination of the paramagnetic susceptibility of substances in solution by nuclear magnetic resonance. J. Chem. Soc. 1959, 2003-2005.

8. Löliger, J.; Scheffold, R., Paramagnetic Moment Measurements by NMR. A Micro Technique. J. Chem. Ed. 1972, 49, 646-647.

9. $\quad$ Shin, B.; Sutherlin, K. D.; Ohta, T.; Ogura, T.; Solomon, E. I.; Cho, J., Reactivity of a Cobalt(III)-Hydroperoxo Complex in Electrophilic Reactions. Inorg. Chem. 2016, 55, 1239112399.

10. Stoll, S.; Schweiger, A., EasySpin, a Comprehensive Software Package for Spectral Simulation and Analysis in EPR. J. Magn. Res. 2006, 178 (1), 42-45.

11. Bruker APEX3, Bruker Analytical X-ray Instruments Inc.: Madison, WIsconsin, USA, 2016. 12. Bruker SAINT., Bruker Analytical X-ray Instruments Inc.: Madison, Wisconson, USA, 2016. 13. Sheldrick, G. M., Crystal Structure Refinement with SHELXL. Acta Cryst. 2015, C71, 3-8.

14. Dolomanov, O. V.; Bourhis, L. J.; Glldea, R. J.; Howard, J. A. K.; Puschmann, H., OLEX2: A complete structure solution, refinement and analysis program. J. Appl. Cryst. 2009, 42 (2), 339341.

15. Gale, E. M.; Atanasova, I.; Blasi, F.; Ay, I.; Caravan, P., A Manganese Alternative to Gadolinium for MRI Contrast. J. Am. Chem. Soc. 2015, 137 (49), 15548-15557. 